\title{
The New Constitutional Developments in the Republic of Liberia
}

\author{
by Gerold W. Schmidt
}

\section{Historical-Political Background}

The history of the Republic of Liberia in West Africa, with approx. 43000 sq. miles and a population of approx. 1.8 million $^{1}$, began in 1821 when the private American Colonization Society (ACS) acquired settlement rights by treaty with native chiefs of what was then known as the Pepper, Grain or Green Coast of Africa, so named by Portuguese seafarers since 1461. The ACS consequently assisted enterprising free born or freed coloured or black Americans, not slaves in the legal sense, including many light-skinned mulattos, some of them with some education and/or capital, to emigrate to Africa in order to reduce the growing black population in the US and forestall the racial troubles anticipated already then, but equally to christianize and civilize the local wild African tribes.

In 1847 , in order to clarify the ambiguous international legal status of the now several and united settlements for shipping and commercial purposes, the immigrants declared themselves independent as the Republic of Liberia with a constitution and institutions closely modelled and based on the US constitution, its institutions, practices and experiences ${ }^{2}$. The new state, quickly recognized by Great Britain and Hamburg, among others, was the first modern republic if not state in black Africa and for a whole century with Ethiopia the only independent African states until colonies began to gain independence.

Politically, economically, legally and sociologically Liberia has been characterized by the dualism, if not antogonism, of the immigrant and native populations. The first, the Americo-Liberians, their number enlarged by the "Congos", the liberated cargoes of sla-

1 Size: Disputed, 37734 or 38250 or 43000 square miles, for latest status see Karl-Heinz Hasselmann, Liberia: Geographical Mosaics of the Land and the People, 1979, Monrovia/Lagos/New York, N. Y.: Ministry of Information, Cultural Affairs \& Tourism/Third World Press International, div. of Okpaku Communications Corp., 54-57. Population: 1.8 million, see The Redeemer, Vol. 1 No. 17, 24. 1980, 1.

2 Charles Huberich, A Political and Legislative History of Liberia, 1947, New York, N. Y.: Central Book Co., Inc., 2 vols.; The Constitution of the Republic of Liberia and the Declaration of Independence, with notes by Alfonso K. Dormu, New York, N. Y. 1970; C. Abayomi Cassell, Liberia, A History of the First African Republic, 1970, New York, N. Y.: Fountainhead Publishers; S. Doris Banks-Henries, The Liberian Nation, A Short History, 1974², New York, N. Y.; Collier Macmillan Intern. Also: Anthony J. Nimley, The Liberian Bureaucracy, An Analysis and Evaluation of the Environment, Structure and Functions, 1977, Washington, DC: University Press of America; Robert Kappel, Liberia, wirtschaftliche und politische Entwicklung 1971-1980. Arbeiten aus dem Institut für Afrika-Kunde. Hamburg 1980. 
veships captured on the high seas, completely followed Western concepts and customs not only in their political constitution and laws, but equally in their Christian religion, political parties and social groupings, in dress and architecture of churches and homes, in business and agriculture to the extent of showing a totally alien, un-African implement in the African State's Great Seal, a plow. The descendents of these pioneeres and founders continued the American connection culturally and legally by e.g. regularly acquiring their higher education in the USA. Although never numbering more than 3 to $5 \%$, the Americo-Liberians have until April 12, 1980 governed and dominated Liberia politically, economically and legally thus giving Liberia its unique character with its US styled English, with American school books, laws, the US Dollar as currency etc.

The original African population, divided into 15 tribes and different language groups, followed and follow African traditions and cultures, African concepts and customs, being prodominantly animistic or - increasingly - muslim, with polygamy, hut-building and subsistence farming on the level of shifting cultivation and slash-and-burn. Politically they had, contrary to other West African tribes and areas, remained on the level of loosely-joined tribes, and had never developed states. These tribes engaged in frequent inter-tribal wars.

Relations between the two groups have changed and progressed from initial defence of the outnumbered immigrants against hostile tribes, to mediation between and forcible pacification of warring tribes by the young and growing state, to domination, subjugation and exploitation by the established state and its mostly Americo-Liberian officials. Only after the second world war efforts towards participation, assimilation and integration began. While the Americo-Liberians were never legally or formally "closed" to tribal Liberians, and intermarriages, the adoption of their own illegitimate or tribal children, etc. always took place, their totally different educational and cultural standards coupled with their greater wealth in many instances tended to give them the "breeding", the manners and outlook similar to an aristocracy which, while not formally closed, tries to preserve its values, standards and positions making them more or less difficult to attain by interlopers or outsiders. Undoubtedly, ever increasing numbers of Liberians of tribal origin through improved educational facilities, national and international scholarships have joined the educated class and have increasingly reached higher and highest ranks on all levels of society. This latter development has been judged internally as well as externally as too slow and too late, resulting internally in increasing awareness, impatience and unrest.

On the whole there appears to be a consensus among the majority of Liberians and foreign observers alike that the performance and achievements of the Americo-Liberians in development, economic, social, legal etc., i. e. in terms of statecraft as well as a class have to be considered as negative, as a failure.

The famous German africanist Diedrich Westermann came to the following conclusion: "On the whole one has to say that with the establishment of Liberia the Liberians were charged with a task which was in excess of their means. Would they have had such training and equipment as today several colonial natives and Africans with roots in their na- 
tive soil receive, the prospects for a success off the experiment would have been less unfavourable. ${ }^{2 \mathrm{a}}$ This was written in 1952.

On April 12, 1980, however, a military coup by tribal soldiers, officially declared as a "revolution" and by the majority of Liberians understood and welcomed as such, against the Liberian government and, understood as such, against the 133 year long rule, exploitation, colonialism etc. of the Americo-Liberians overthrew the Liberian government. ${ }^{3}$ Since then a reappraisal of Liberia's constitutional and legal system has begun and radical constitutional changes have already occurred. A first analysis of the new legal situation in Liberia is hereby attempted. ${ }^{4}$

\section{The Constitution of $\mathbf{1 8 4 7 - 1 9 8 0}$}

\subsection{Outline}

The Liberian Constitution of July 29, 1980 until April 12, 1980 was commissioned by the American Colonization Society, drafted by the eminent Harvard Law Professor Simon Greenleaf (1783-1853) ${ }^{5}$, amended and adopted in Liberia, July 29, 1847. ${ }^{6}$

This Liberian Constitution, ${ }^{7}$ in this instance learning from and improving on its model, the US constitution, after a "Preamble", opened with "Article I. Declaration of Rights" which was subdivided into 20 Sections and commonly called the "Bill of Rights". ${ }^{8}$ "Article II. Legislative Powers" established a "House of Representatives" elected by the property-owning inhabitants in proportion to population (Section 2) and a "Senate" consisting of two members each from the - now nine - "Counties", i.e. centrally governed provinces, elected equally by the respective inhabitants (Section 5). "Every bill or resolution which shall have passed both branches of the legislature shall, before it becomes a law, be laid before the President for his approval" (Section 10).

"Article III. Executive Powers" provided: "The Supreme Executive Power shall be vested in a President who shall be elected by the people", who is Commander-in-Chief of the Army and shall, with the advice and consent of the Senate, appoint and commission the Secretaries - now Ministers - of State, of the Treasury - now Finance -, etc., Am-

2a Diedrich Westermann, Geschichte Afrikas, Staatenbildungen südlich der Sahara, Köln 1952, S. 211.

3 Time Magazine, 21. 4. 1980, 31: "Coup at Dawn;" Africa (London), No. 105, May 1980, 35-37: "Tolbert's Overthrow"; New African (London), No. 153, May 1980, 24-27: "The Gathering Storm" and "End of an Era"; West Africa (London), No. 3274, 21. 4. 1980, 87, 89-91: "Death of a Liberian Regime"; J.-B. Alima, La Rèvolte des 'Indigènes'", Jeune Af rique, Vol. 20, No. 1007, 23. 4. 1980, 18-22.

4 Gerold Schmidt, Zur neuen Rechts- und Verfassungslage in der Republik Liberia, Heidelberg: Recht der Internationalen Wirtschaft (RIW/AWD) 1981 (March), 160-165.

5 Short Biography in Banks-Henries (Footnote 2), 275-27.

6 Cassell, (Footnote 2), 132-139.

7 For version effective until 12.4. 1980 see: Liberian Code of Laws Revised, Adopted by the Legislature of the Republic of Liberia, published under the Authority of the Legislature of Liberia and President William R. Tolbert, Jr., Volume I, 1973, Ithaca, N. Y.: Cornell University Press, 1-18; for original, historical version see Cassell (Footnote 2), Appendix 5, 415-430 and Banks-Henries (Footnote 2), Appendix VIII, 290-302.

8 Banks-Henries (Footnote 2), Appendix IX: "Amendments to the Constitution", 303-310. 
bassadors, Judges etc. (Section 1). There was a Vice-President who served as President of the Senate (Section 2).

"Article IV. Judicial Department" provided for a Supreme Court and subordinate courts (Section 1), the Supreme Court having apellate jurisdiction, both as to law and fact. Finally, "Article V. Miscellaneous Provisions" contained 17 Sections dealing with a variety of subject matters including the provisions on citizenship requirements and on constitutional amendments (Section 17). As of April 12, 1980, indeed a number of amendments had been made ${ }^{8}$ which, however, had not altered the basic structure outlined above.

\subsection{Pending, but not effected amendments}

At the time of the coup, two fundamental constitutional amendments were discussed or in legal process.

In October 1979, the assassinated President William R. Tolbert proposed amending the citizenship provision according to which "none but Negroes or persons of Negro descent shall be eligible to citizenship in this Republic, the great object of forming these Colonies being to provide a home for the dispersed and oppressed children of Africa and to regenerate and enlighten this benighted Continent" (Art. V, Sect. 13). ${ }^{9}$ This provision in connection with Art. V, Sect. 11 according to which "no person shall be entitled to hold real estate in this Republic unless he be a citizen of the same", precluded real estate ownership by foreigners and foreign owned corporations. ${ }^{10}$ This legal situation was felt to stifle investment and thereby development including development of suitable architecture and durable construction since many foreign business ventures had and have first to erect the necessary premises themselves, on rented lots, however.

The amendment intended to grant citizenship to people other then those of Negroe descent because "certain safeguards embodied in the Constitution have outlived their usefulness" and Liberia was opposed to racism, oppression and suppression, so "it was only rational that those aspects of our organic institutions which indicate any practice contrary to our position were changed to meet changing conditions. "11 This surprise proposal met public approval ${ }^{12}$, but also lively opposition. ${ }^{13}$

9 As Amended 1907; 1847: "none but persons of colour shall" etc.

10 Recently Tuan Wreh, Determining Children's Citizenship under Liberian Law, New Liberian, Vol. 2, 19. 11. 1979, 4.

11 President W. R. Tolbert, in "TWP Congress Adopts Recommendations," New Liberian, Vol. 2 No. 51, 29. 10. 1979, 2 = The Liberian Age, Vol. 33 No. 87, 2. 10. 1979, 4.

12 Editorial "New Horizons", New Liberian, Vol. 2 No. 51, 29. 10. 1979, 2; "A. B. Tolbert on Repeal of Racist Law", The Liberian Age, Vol. 33 No. 92, 13. 11. 1979, 4 = New Liberian, Vol. 2, 12. 11. 1979, 2; T. W. Stewart, The Citizenship and Land Ownership Quagmire, Sunday Express, No. 287, 24. 2. 1980, 2 and 4; N. Kotey, Replacing Racialism with Recialism, New Liberian, Vol. 2 No. 30, 3. 1. 1980, 4.

13 Editorial "A Matter of Survival", Bentol Times, Vol. 1 No. 41, 31. 10. 1979, 1 and 3; C. W. Allen, To Be or Not To Be, The Liberian Inaugural, Vol. 4 No. 45, 21. 11. 1979, 6 and 8; "Chief Justice Urges Preservation of Heritage", Sunday Express, 9. 12. 1979, 3; W. E. Ward, It's Blowing in the Wind, The Sunday People Vol. 1 
A second constitutional amendment concerned the right of suff rage which was constitutionally limited according to Art. I Sect. 11 to "every citizen (Male and Female) of eighteen years of age possessing real estate"; "Possessing real estate schall be construed to include possessing a hut on which he or she pays the hut tax $" 14$, a provision deeply rooted in Anglo-American political and constitutional history. ${ }^{15}$

In 1975, the late President Tolbert recommended to the Legislature "to eliminate the possession of real estate as a prerequisite to the right of suffrage, because it is my conviction that to require an eighteen-year-old to possess real property on which taxes must be paid as a prerequisite to eligibility to vote, would be tantamount to limiting his or her right of suffrage. Moreover, in today's world property requirement as a prerequisite to the exercise of the right to vote is outmoded. $1{ }^{16} \mathrm{~A}$ Bill to this effect was passed by the House of Representatives, but was rejected by the Senate in $1977 .{ }^{17}$

This passed almost unnoticed at the time because the limitation existed more or less in theory only ${ }^{18}$ for two reasons. Due to the lack of a complete voters'roll and general administrative inefficiencies, practically anybody could vote. Secondly, the Liberian de-facto one-party system offered one candidate only anyway; hence the authorities did not care much who voted but were even interested in a large statistical turn-out of the population. However, after the semi-revolutionary upheaval of April 14, 1979 which shook Liberia to the roots, ${ }^{19}$ an independent candidate opposed the "official" candidate in the Monrovia, the nations's capital, mayoral elections and made the constitutional provision an election issue with the slogan: "No Land - No Vote ${ }^{20}{ }^{20}$ This resulted in popular requests to the Senate to pass the rejected amendment and hold the National Referendum required by the Constitution for constitutional changes. ${ }^{21}$

No. 12, 25. 11. 1979, 2; S. H. Cordor, The Search for National Consciousness, New Liberian, Vol. 2. No. 70 , 3. 1. 1980, 4; "Reactions To Citizenship Proposals", New Liberian, Vol. 2 No. 51, 29. 10. 1979, 12; "Whites To Become Citizens? Mixed Reactions Greet Proposal," Sunday Express No. 270, 28. 10. 1979, 3 and 6.

14 As amended, see legislative history in LCL Rev. (Footnote 7), 5 footnote 2.

15 Dr. James T. Tarpeh, Two Worlds of the Property Clause, New Liberian, Vol. 3, No. 10, 10. 4. 1980, 6-7, contd. No. 11, 14. 4. 1980, 3 and 6.

16 Fif th Annual Message, 17. 12. 1975, in: Presidential Papers, The Concluding Period of the First Administration of President William R. Tolbert, Jr. (August 1, 1974 - December 31, 1975), 1976, Monrovia/Tiptree, Essex, UK, 441-442.

17 "Tolbert, Let Justice Be in TWP," Weekend News, Vol. 1 No. 3, 20. 10. 1979, 4; "Election Postponement Raises Constitutional Issue," Bentol Times, Vol. 1 No. 42, 7. 11. 1979, 2; Flemister, TWP Fears No Opposition, New Liberian, 27. 9. 1979, 12.

18 C. Cooper, Rehold Elections, The Sunday People, Vol. 1 No. 9, 4. 11. 1979, 6; J. V. Peabody, Voters Registration, New Liberian, Vol. 2 No. 42, 27. 9. 1979, 7.

19 Comprehensive: S. Henry Cordor, The April 14 Crisis in Liberia, 1979 (June), Monrovia: Mimeographed, 120 pages; New African (London), June 1979, 22-26; West Africa (London), No. 3223, 23. 4. 1979, 700, 728.

20 "People's Movement Will Sweep Away 'NO Land No Voter Law in Liberia," Gweh Feh Kpeh (MOJA), Dec. 1979, 7-8.

21 "Election Postponement Raises Constittuional Issue“, Bentol Times, Vol. 1 No. 42 7. 11. 1979, 2; "Refrerendum: Only Property Owners Will Vote", SCOPE, Vol. 2 No. 31, 13. 12. 1979, 1; "Sawyer Writes Chu-Chu", New Liberian, 1. 10. 1979, 5; "Chu-Chu Replies", New Liberian, 1. 10. 1979, 5. 
Widespread approval of this constitutional change ${ }^{22}$ against only isolated voices upholding the property clause ${ }^{23}$ resulted first in a presidential proposal that the property requirement be replaced by the requirement that citizens who are 18 years and above and who are taxpayers paying the "National Development and Progress Tax" in keeping with the current Revenue and Finance Law schould enjoy the right to vote ${ }^{24}$ which upon public criticism based upon Article 21 of the Universal Declaration of Human Rights, to which Liberia is a signatory, ${ }^{25}$ was modified into the formal recommendation "that the right of voting be enjoyed by all citizens of eligible age without any conditions attached. ( $^{26}$ At the time of the April 12, 1980 coup, the Senate had originated a Bill "An Act to Amend Section 11 of Article I of the Constitution of the Republic of Liberia to Abolish the Property Qualifications for Voters" and had referred it for concurrence to the House of Representatives which had not passed it. ${ }^{27}$

\subsection{Constitutional Reappraisal}

In general, this 133 year old constitution had become a source of public debate and contention at least since 1971, when the removal of the cobwebs in it was demanded to make it compatible with the realities of 20th century Liberia. ${ }^{28}$

More specifically, before and after the coup, the references to the American settlers and founders in the above quoted citizenship provision of the Constitution, ${ }^{29}$ but particularly the Declaration of Independence with "We, the people of the Republic of Liberia were originally the inhabitants ${ }^{30}$ of the United States of North America" and the reference to "this barbarous coast ${ }^{31}$, have been increasingly criticized ${ }^{32}$ as "colored with anachroni-

22 C. W. Allen, A Plea Reincarnated, The Sunday People, Vol. 1 No. 7, 21. 10. 1979, 3; Chea Cheapo, The Sunday People, Vol. 1 No. 8, 28. 10. 1979, 2 and 7; S. A. Quellie New Liberian, Vol. 2 No. 52, 1. 11. 1979, 7; R. E. Marshall, Remove The Property Clause But Create Measures That Only Liberians Vote, The Liberian Age, Vol. 33 No. 87, 2. 10. 1979, 5 and 12.

23 Carter, Don't Remove Property Clause, New Liberian, Vol. 2 No. 49, 22. 10. 1979, 5.

24 "Tax Payment as Basis for Voting Proposed,"The Liberian Inaugural, Vol. 4 No. 42, 31. 10. 1979, 1.

25 "Dr. Sawyer Opposes any Voting Qualifications", Weekend News, Vol. 1 No., 10. 11. 1979, 1.

26 Ninth Annual Message to the Legislature, by Pres. W. R. Tolbert, The Liberian Ag. Vol. 33 No. 6, 25. 1. 1980, 1 = Weekend News, Vol. 1 No. 17, 2. 1. 1980, 1; "Amos Sawyer on Property Clause", The Liberian Inaugural, Vol. 5 No. 5, 30.1. 1980.

27 "Mayoral Race Heats Up," Bentol Times, Vol. 2 No. 2, 2. 3. 1980, 1 and 4; "Nation wide Support Seen in PPP-Banning", The Liberian Age, Vol. 33 No. 24, 1.4. 1980, 5 = "Legislature Bans PPP«, New Liberian, Vol. 2, 31. 3. 1980, 6 .

28 Dr. Abeodu Jones as quoted by E. Osadebay, Towards Our National Reconstruction Efforts, The Redeemer, Vol. 1 No. 5, 13. 5. 1980, 5.

29 Osadebay (Footnote 28).

30 Commonly misquoted in Liberia as "citizens of the U. S.", e. g. "Sinoe Youth: Change These Now," Weekend News, Vol. 1 No. 31, 2. 4. 1980, 3; see Nimley (Footnote 2) 13-137: Settlers were legally not citizens of USA.

31 Declaration of Independence, in: Banks-Henries (Footnote 2), Appendix VII, 286-28 .

32 Albert Porte, Thoughts On Change, 28. 4. 1977: Monrovia, Mimeographed Pamphlet; Osadebay (Footnote 28); Derick Day, Uniting To Rebuild Liberia, The Redeemer, Vol. 1 No. 5, 13. 5. 1980, 4; Albert Porte, The Liberian Declaration of Independence: A Revised Version, New Liberian, Vol. 3 No. 18, 3. 7. 1980, 4. 
stic statements" and as having "introduced a contradictory note into the national life of a nation conceived in liberty ${ }^{33}$, in short, as exluding and negating the majority of Liberians, i.e. the indigenous tribal Africans. ${ }^{34}$

Into this same line of constitutional criticism belong the requests, before and after the coup, to change the Liberian flag modelled after the US flag but with 11, i.e. 6 red and 5 white, stripes and one white star - "The Lone Star" - in a blue field, "because Liberia has just been reborn", and the Liberian State Motto "The Love of Liberty Brought us Here", because "as Liberians they came from nowhere but right here. ${ }^{35}$

Regarding the functioning of the balance of power provided in the Liberian Constitution Liberian criticism had become increasingly negative. Shortly before the coup the National Catholic Secretariat held publicly: "A long-term result has been the gradual absorption of both legislative and judicial powers by the Executive, at least indirectly," which "have brought to the Executive Branch of Government a tradition and expectation of powers of wide dimension. " $^{36}$

After April 12, 1980, the Chairman of the People's Redemption Council of the Armed Forces of Liberia, which had taken over the government, and new Head of State, Master-Sergeant Samuel. K. Doe, reiterated this constitutional criticism. While in his first address to the Liberian nation on April 14, 1980 he stated that "the Tolbert Government had to be removed because, we all know; it disregarded the civil, human and constitutional rights of the Liberian people, ${ }^{\prime 37} \mathrm{a}$ statement which found wide popular acclaim, ${ }^{38}$ in a subsequent address he declared: "The balance of power which the seperation of the Executive, the Legislative and Judiciary branches of Government was supposed to have brought about, never worked. The President and his main coworkers went through a false procedure to pass laws. The Judiciary was a mockery in many instances because cases were determined by how much money one could offer. (139 $^{39}$

It is apparently on the basis of this assessment that a radical break and constitutional change has now occurred in Liberia.

33 Day (Footnote 32).

34 Day (Footnote 32): "inescapable conclusion that the indigenes were not accorded full citizenship status from the onset".

35 See e. g. Day (Footnote 32) and "Sinoe Youth" (Footnote 30); M. Bruce, The Redeemer Vol. 1, No. 5, 13. 5. $1980,6$.

36 The Future of Liberian Society, A Challenge for the Eighties, Published by: The National Catholic Secretariat (7th Installment), in: The Sunday People, Vol. 2, 1. 3. 1980, 4; see also Nimley (Footnote 2) 113-125 (E).

37 Express Special, No. 9, 17. 4. 1980, 3 (paragraph 3). Now continuously repeated.

38 E. g. E. F. Kruah, Liberia on a New Historical Page, New Liberian Vol. 3 No. 12, 21. 4. 1980, 7; S. Swaray, New Liberian, Vol. 3 No. 13, 24. 4. 1980, 8.

39 Express Special, No. 11, 23. 4. 1980, 5. See also Albert Porte, New Liberian, Vol. 3 No. 12, 21. 4. 1980, 3: "the inert rubber-stamp one-party Whig Legislature" etc. 


\section{The new Constitution of April 24, 1980}

\subsection{Decrees}

The new masters of Liberia have begun to rule the country by "Decree of the People's Redemption Council of the Armed Forces of Liberia", (PRC) a legal term and form new and unknown in Liberian legal terminology and practice which knew formal "laws" passed by "act" of the Legislature. ${ }^{40}$ However, "Executive Orders" and "Executive Ordinances ${ }^{41}$ have also been issued, thereby continuing the previous profusion of little defined or differentiated non-formal law which also knew "Executive Circulars" and "Regulations" ${ }^{42}$ These "Decrees", according to their last, unnumbered paragraph, shall take effect immediately upon the signature of the Head of State of the Republic of Liberia, i. e. the Chairman of the PRC. The "Decrees" have been officially published only in "Handbills", ${ }^{42 a} \mathrm{i}$. e. on loose sheets of paper, which is consistent with Liberian legal development which has not yet achieved a regular legal publication of laws etc.; "Session Laws", i. e. printed collections of all acts passed by the Legislature during a given session which were published regularly during the 1950 ies and 60 ies have ceased to appear. It is No. 2 of these Decrees, dated April 24. 1980, commonly called Drecree suspending the Constitution and declaring martial law, ${ }^{43}$ consisting of 6 numbered paragraphs which will be referred to as Sections hereafter, that the new constitution of the Republic of Liberia is contained, even if not formally called so.

\subsection{Suspension of the Constitution of $\mathbf{1 8 4 7}$}

Section 1 decrees: "1. The Constitution of the Republic of Liberia, as amended through April 12, 1980, and the three branches of Government established thereunder are hereby suspended."

2.2.1 The complete suspension of the Constitution which apparently came as a surpri$\mathrm{se}^{44}$ logically implies and includes the supension of the three branches of Government

40 See LCL Rev. (Footnote 7), Vii-VIII: Complete List of 39 "Laws".

41 Executive Order No. 4, 3. 7. 1980, on Govt. Agencies to collaborate with Ministry of Justice when they engage in negotiation, legal agreements and financial construction, The Redeemer, Vol. 1 No. 20, 4. 7. 1980, 7 ; used synonymously with "Executive Ordinance," see Executive Ordinance No. 5, 4. 7. 1980, on New Policy for Public Corporations, The Redeemer, Vol. 1 No. 21, 7. 8. 1980, 1.

42 E.g. "Executive Circular No. 2 (1980)", of Ministry of Commerce, Industry and Transportation, Increase in Price of Petrolum Products, Sunday Express No. 308, 27. 7. 1980, 5; for No. 1 (1980) see Bentol Times, Vol. 2 No. 52, 1. 1. 1980, 6. "Forestry Development Authority Regelation No. 7 on Revised Forest Fees and Taxes," 7. 12. 1979, in: FDA Newletter, Vol. 2 No. 7, 7. 12. 1979, 5 pages (mineographed).

42a See, however, leaflet: Seven Decrees of the People's Redemption Council, Prod. byPublic Affairs Bureau, Ministry of Information, Cultural Affairs \& Tourism, Monrovia 1980, $10 \mathrm{pp}$.

43 The Sunday People, Vol. 1 No. 17, 27. 4. 1980, 1 and $8=$ Weekend News, Vol. 1 No. 31, 2. 4. 1980, 1 = Decree No. 2 (see Footnote 42a aboue) pp. 3-4.

44 New Director of Govt. Spec. Security Service before Decree of 24. 4. 1980 considered himself and SSS employees "under oath to protect Head of State and to defend the Constitution of Liberia". 
established thereunder, so that their express suspension appears to be a superfluous repetition, legally. However, in the light of the negative appraisal of the Constitution of 1847 by the PRC-Chairman, quoted above, this seeming repetition could be interpreted to mean and emphasize a complete break of the new Liberia with the old Liberia.

This interpretation seems to be supported by the fact, that the PRC Chairman and Head of State in an address to Senior Army Officiers, on April 16, 1980, had already abolished Liberia's "Independence Day" since 1847, i. e. July 26, because "said July 26, 1847 was a day when the Liberian people became prisoners on their own soil and were deprived of the fruits of their land ", "they were finally redeemed on April 12, 1980 and their dreams of true freedeom have come true. ${ }^{45}$

Against only isolated dissent pointing out historical reality ${ }^{46}$ and that the previous Governments only "misused the Bye-Laws and constitutions laid down by J. J. Roberts (i. e. Liberias 1. President, 1847) and others ${ }^{477}$, the reasons given for the abolition of the traditional Independence Day have found wide-spread acclaim, because na fingerfulgroup of westernized freed American slaves from the USA invaded our people ${ }^{48}$ and "July 26, 1847 was the time the typical Liberian people became slaves to the ex-slaves from America, "49 so that "for the past 133 years Liberians have been living in slavery until April 12, 1980 " ${ }^{50}$; "after more than 133 years of dictatorship and subjugation in the form of suppression, exploitation, economic extravagance, corruption, human degradation and gross violation of human rights " ${ }^{51}$ "the liberation of the Liberian people from colonialists in black skin " ${ }^{52}$ has now occurred, "liberating our beloved country ${ }^{53}$, "bringing the Liberian people out of captivity ${ }^{54}$, so that they are now "liberated from the shackles of oppression, injustice and slavery ${ }^{45}$; therefore, "April 12 should be regarded as the Independence Day of Liberia. ${ }^{56}$

Under international law this total disassociation from the historical, political and legal past of Liberia by the new Liberian rulers and the people raises the question of the legal identity of the state of Liberia since April 12, 1980 with the state of Liberia known before that date, such question resulting in further questions regarding diplomatic recognition, representation in international organizations etc. If Liberia had become independent indeed only on April 12,1980, it would not be Africa's first and oldest republic, but Africa's and probably the World's second youngest state having beaten Zimbabwe

45 Express Special, No. 10, 18. 4. 1980, 1.

46 Editorial, New Liberian, Vol. 3 No. 12, 21. 4. 1980, 2.

47 G. Gweh, New Liberian, Vol. 3 No. 19, 7. 7. 1980, 5; W. Gayflor, New Liberian, Vol. 3 No. 21, 14. 7. 1980, 5; M. D. Karnuah, The Redeemer, Vol. 1 No. 24, 18. 7. 1980, 5.

48 A. G. Myers, The Meaning Behind a Revolution, The Redeemer, Vol. 1. No. 16, 20. 6. $1980,4$.

49 J. K. Solo, New Liberian, Vol. 3 No. 13, 24. 4. 1980, 8.

50 Commanding General Quiwonkpa, The Sunday People, Vol. 2 No. 19, 11. 5. 1980, 1.

51 E. F. Kruah, Liberia on a New Historial Page, New Liberian, Vol. 3 No. 12, 21. 4. $1980,7$.

52 A. G. Domah, The Redeemer Vol. 1 No. 2, 2. 5. 1980, 11.

53 G. Slopa-Doe, New Liberian, Vol. 3 No. 13, 24. 4. 1980, 8

54 Claratown Youth Assoc., Express Special No. 13, 7. 5. 1980, 5.

55 Nimba Women Assoc., The Sunday People, Vol. 5 No. 17, 23. 4. 1980, 4.

56 D. George, New Liberian, Vol. 3 No. 13, 24. 4. 1980, 8. 
(Rhodesia) to it by only a few days. Initial refusals to recognize the Liberian delegation as such ${ }^{57}$ and continuous refusals to admit the PRC-Chairman and Head of State of Liberia $^{58}$ to meetings of ECOWAS and OAU of which Liberia was a founding member, may have been based, inter alia, on such legal interpretations of Liberia's own position regarding its identity. While continuing references to and pride in Liberia's being the oldest independent African republic ${ }^{59}$ rather makes it a case of eating one's legal cake and have it, too, the new Liberian government has consistently declared "that the PRC would adhere to all foreign committments and agreements between Liberia and other nations of the international community, be they bilateral or multilateral. ${ }^{60}$ Therefore, the question of legal identity schould be answered in the affirmative, and not only because July 26, 1847 was later officially retained as Liberia's Independence Day.

However, the revolutionary-political declarations that the Liberians were "invaded", "enslaved", "deprived of their land" etc. raises, probably unintentionally, a historical problem in international law. It has so for been official Liberian, i. e. Americo-Liberian, legal doctrine that the land acquisition by the American Colonization Society from the African tribes in 1821 was legally valid under international law practices of the time as e. g. confirmed by the Congress of Berlin (1885). ${ }^{61}$ Recent Afro-Liberian studies, however, reappraise the issue under national or municipal-local i. e. African tribal law of the time which had - and still has - not developed individual real property and thereby no land transfer or acquisition with the consequence that the agreements of the American Colonization Society and all subsequent private titles in Liberia are held to be null and void. ${ }^{62}$ No official position on this is known yet. ${ }^{63}$

2.2.2 The total suspension of the Constitution of 1847 further includes "Article I, Declaration of Rights", which in Section 20 guarantees the right of Habeas Corpus. Section 6 of the Decree repeats: "6. The right of Habeas Corpus is hereby suspended and martial law is thereby established until otherwise ordered by the People's Redemption Council."

57 Lagos OAU Economic Ministerial Conference: The Sunday People, Vol 2 No. 17, 27. 4. 1980, 8; Africa (London), No. 107, July 1980, 18; The Sunday People, Vol. 5 No. 18, 30. 4. 1980, 8.

58 ECOWAS Summit, Lome/Togo: Africa (London) No. 107, July 1980, 18.

59 Osadebay, The Redeemer, Vol. 1 No. 15, 13. 5. 1980, 5; Weekend News, Vol. 1 No. 42, 12. 7. 1980, 1.

60 Foreign Minister Matthews, Address to Diplomatic Corps, Sunday Express, No. 294, 20. 4. 1980, 1 = The Sunday People, Vol. 2 No. 16, 20. 4. 1980, 5. Economics Minister Dr. Tipoteh, State of Economy, Sunday Express, No. 295, 27. 4. 1980, 8. Finance Minister Zulu, The Redeemer, Vol. 1 No. 4, 9. 5. 1980, 1; PRC Statement on Economic Policies, The Redeemer, Vol. 1 No. 13, 2 ("Basic Policies" 2).

61 Karmo v. Morris (1919), in: Liberian Law Reports, Cases Adjudged in the Supreme Court of the Republik of Liberia, Jan. 1908 - Nov. 1920, Vol. 2, Ithaca, N. Y. (Cornell University Press) 1960, 317-334; James E. Pierre, Chief Justice, Sunday Express, No. 288, 2. 3. 1980, 4-5, continued in Bentol Times, Vol. 2 No. 59, 5. 3. 1980,2 and 4.

62 A. J. Nimley (see Footnote 2 above), 126-159.

63 See however Minister for Local Government Quiah, Weekend News, Vol. 1 No. 32, 3. 5. 1980, 3 = Express Special, No. 12, 30. 4. 1980, 4 = The Redeemer, Vol. 1 No. 1, 29.4. 1980, 2: "All land unjustifiably taken from the people of Bong County by 'Big Shots' will be returned to the people." Against: The Liberian Inaugural, Vol. 5 No. 18, 30. 4. 1980, 3: "it is too soon to start talking about people's land being returned to them," warning against "seizing legally acquired lands at random." 
While the finer legal difference between "military law" and "martial law" is being publicly discussed, ${ }^{64}$ the total suspension of all civil rights is not fully realized.

Even before the formal suspension of the Liberian Bill of Rights on April 24, 1980, a Special Military Tribunal on April 15, 1980 began proceedings based apparently on a P RC-"Act" ${ }^{65}$ i. e. on retroactive penal law, against Government Ministers, active and retired, Members of the House of Representative and of the Senate, party of ficials etc. most of whom had been arrested, treated and detained under degrading circumstances. ${ }^{66}$ In these proceedings the constitutional rights to orderly trial, to defense by lawyer etc. had been disregarded and as a result, 13 victims were shot under inhuman circumstances, ${ }^{67}$ which led to international pressure, ${ }^{68}$ upon which the executions were stopped. ${ }^{69}$ An unknown number of prisoners is still held not by the civil authorities, but by the military, not in civil jails, but in a so-called "Post Stockade" wihin a military barracks which could be termed a concentration camp. The Special Military Tribunal has ceased trying them and their future is unknown. Most leading members of the legal profession in Liberia are suffering this fate..$^{70}$ Also, the constitutional right to form political parties ${ }^{71}$ - until March 31, 1980 Liberia had two registered political parties ${ }^{72}$ with a third said to be organizing ${ }^{73}$ - has been suspended. The party forming the government until April 12, 1980 is consistently called to be "defunct ${ }^{74}$ from which must be concluded that it has been outlawed though a formal legal decision is not known. ${ }^{75} \mathrm{~A}$ further prominent political movement out of which several cabinet members of the new government originate,

64 Prof. Tuan Wreh, Adjudication of Labour Disputes Under Military Rule, The Redeemer, Vol. 1 No. 21, 8. 7. $1980,4$.

65 "The Act of High Treason", New Liberian, Vol. 3 No. 12, 21. 4. 1980, 1 = Scope, 12. 6. 1980, 1 = PRC Decree No. 1 (see Footnote 42a above) p. 1-3.

66 West Africa (London), No. 3275, 28. 4. 1980, 729-730, 762-763, 727.

67 Time Magazine, 28. 4. 1980, 23: "After Take-Over Revenge«; Newsweek, 28. 4. 1980, 14: "The Sergeant-President", and 5. 5. 1980, 29: "Sergeant Doe's Death Squad".

68 The Sunday People, Vol. 2 No. 17, 27. 4. 1980, 1: "World Bodies Appeal To PRC, Clemency Pleas For ExGovt. Officials"; Sunday Express No. 295, 27. 4. 1980, 2: "Clemency Messages"; New Liberian, Vol. 1 No. 31, 26. 4. 1980, 2, Editorial.

69 "No More Executions", The Liberian Inaugural, Vol. 5 No. 18, 30. 4. 1980, 1 = Express Special, No. 12, 30. 4. 1980,1 = FOCUS, Vol. 2 No. 18, 27. 4.-3. 5. 1980, 1 = The Redeemer, Vol. 1 No. 2, 2. 5. 1980, 6 (full text of address by Doe) $=$ The Liberian Inaugural, Vol. 5 No. 18, 30. 4. 1980, 3 .

70 See "Persons Listed By PRC To Face Tribunal, "The Sunday People Vol. 2 No. 17, 27. 4. 1980, 6, Group $7=$ Sunday Express, No. 295, 27. 4. 1980, 6.

71 See - before 12. 4. 1980! - "No Plans for One Party System," The Liberian Age, Vol. 33 No. 99, 11. 12. 1980, 4.

72 "Legislature Bans PPP," New Liberian, Vol. 3 No. 7, 31. 3. 1980, 6; see Footnote 27 above.

73 "Another Opposition Party for Liberia?, People's Democratic Party in Formation," Bentol Times, Vol. 2 No. 53, 23. 1. 1980, 1.

74 E. g. The Sunday People, Vol. 2 No. 16, 20. 4. 1980, 1; New Liberian, Vol. 3 No. 13, 24. 4. 1980, 1: The Redeemer, Vol. 1 No. 1, 29. 4. 1980, 1.

75 See, however, "The Act of High Treason", (Footnote 65 above); "ex-of ficials would be guilty of treason if they were members of a political party which, in contravention of the democratic process, monopolized political control and participation to the exclusion of the citizens." See also PRC Decree No. 7, 7. 7. 1980 "conf iscating all the wealth, real and personal properties of the deposed William R. Tolbert, Jr.", The Redeemer, Vol. 1 No. 21, 8. 7. 1980, 1; "Convicted Officials To Lose Assets," The Liberian Inaugural, Vol. 5 No. 19, 7. 5. 1981. 
has voluntarily suspended its political activities because it interprets the suspension of the Constitution as "banning of all political activities." $" 76$

The right to free movement, apart from a still continuing nightly curfew ${ }^{77}$, has been restricted by the requirement for Liberians intending to travel out of the country to acquire an Exit Permit from the Commanding General of the Armed Forces of Liberia while the criteria and conditions for the issuance of these Permits have not been made public; ${ }^{78}$ However, on June 18, 1980 a letter - "directive" - of the PRC-Chairman and Head of State to the Commanding General was published according to which Exit Permits will not be issued to Liberians wishing to travel out of the country until otherwise ordered. ${ }^{79}$ Upon public criticism, ${ }^{80}$ the Ministry of Justice declared the measure as being "merely for security reasons and not per se to restrict the movement of Liberians" ${ }^{81}$

Regarding the Freedom of the Press it is rather surprisingly believed that it has not bcen suspended with the suspension of the Bill of Rights, but, on the contrary, "that the press was being granted full freedom to report and inform. ${ }^{82}$ The suspension also includes the suspension of the "Property Clause", i. e. the property restriction of the right to vote, as well as the provision limiting Liberian citizenship to negroes, a probably rather unexpected if not undesired result of the total suspension of the Constitution effective from July 26, 1847 to April 12, 1980.

76 "Moja suspends all political activities," The Liberian Inaugural, Vol. 5 No. 20, 14. 5. 1980, 1. Apparently equally suspended are Masonic Lodges etc., see Foreign Minister Matthews, The Redeemer, Vol. 1 No. 14, 13. 6. 1980, 8: whe was nut a member of any fraternity because such organisations are contrary to the continued existence of good government, ethics and morality «; Students of the New Liberia, The Redeemer, Vol. 1 No. 4, 9. 5. 1980, 6: "enemies of the state" (IV, 9); "More Human Skulls Discovered," New Liberian, Vol. 3, No. 15, 23. 6. 1980, 8; "UBF Men Arrested, "SCOP E, 3. 7. 1980, 6 and 7; See also "What is Free Masonry", The Sunday People, Vol. 2 No. 31, 3. 8. 1980, 6; Gerold Schmidt, Freimaurerverf olgung in Liberia, Humanität, Das deutsche Freimaurer Magazin Nr. 6/Nov.-Dez. 1980, s. 23-26.

77 "Curfew Time Extended To 1.00 a. m.," The Redeemer, Vol. 1 No. 28, 1. 8. 1980, 1 = Sunday Express, No. 309, 3. 8. 1980, 1. See previously: "Curfew Time Shifted", The Redeemer, Vol. 1 No. 1, 29. 4. 1980, 8: "Residents Advised To Observe Curfew," The Redeemer, Vol. 1, No. 17, 1 24. 6. 1980, 1; "Off-Shore Fishing at all hours permitted now," Weekend News, Vol. 1 No. 41, 5. 7. 1980, 6.

78 "Exit Permits Frozen", The Liberian Inaugural, Vol. 5 No. 25, 1980, 1 and 8 = Sunday Express, No. 303, 22. 6. $1980,2$.

79 The measure is said to have been prompted by the large-scale defections and exodus of Liberians from Liberia, including - unannounced - 2 cabinet ministers and other high government of ficials, see B. N. Bropleh, "Whither Thou?", The Redeemer, Vol. 1 No. 28, 1. 8. 1980, 5; see Footnote 104a below.

80 Dr. Amos Sawyer, "Protect Right To Travel", New Liberian, Vol. 3 No. 16, 26. 6. 1980, 8: "should be protected as a basic human right, " "ban on travel could to a large extent give the outside world the impression that our Government is not in control".

81 "Liberians Can Now Travel", The Redeemer, Vol. 1 No. 20, 14 @ Weekend News, Vol. 2 No. 41, 5. 7. 1980, 1 $=$ The Sunday People, Vol. 2 No. 27, 6. 7. 1980, 3.

82 "Press Freedom At Last," FOCUS, Vol. 2 No. 17, 20.-26. 4. 1980, 1. While the right to form Labour Unions does not seem to be impaired, PRC Decree No. 12, 23. 7. 1980, Abolishes Strikes, New Liberian, Vol. 3 No. 24, 24. 7. 1980, 8 = Sunday Express, No. 308, 27. 7. 1980 2; upon public criticism, however, PRC Chairman Doe, "Decree not intended to curtail Workers' rights, "The Express, No. 26, 6. 8. 1980, 1; see also Sunday Express, No. 308, 27. 7. 1980, 3; therefore, "Decree 12 To Be Reviewed," The Sunday People, Vol. 2 No. 31 , 3.8. 1980, 1 . 


\subsection{The New Constitution of April 24, 1980}

Section 2 of the new constitutional Decree provides: "2. During the period of suspension of the Constitution all legislative powers and all executive powers shall be vested in the People's Redemption Council presided over by its Chairman." while Section 5 decrees: "5. The People's Redemption Council shall set up and establish special tribunals by decrees for handling of matters of judicial nature previously handled by the judicial branch of Government."

\subsubsection{Legislative Powers}

While all legislative powers are thereby vested in the PRC, this does not mean that all existing laws from the former legislature have ceased to be valid; this is clarified by Section 3: "3. All laws now in force in the Republic of Liberia other than than the Constitution shall be in force as laws of the Republic of Liberia, until they shall be repealed or amended by the People's Redemption Council." The latter part of this Section which is also found in Section 4 on the laws relating to the Executive, however, with slight language variations: instead of "until they shall be repealed etc." Section 4 reads: "until they are repealed or amended by etc." - states the extent of the legislative powers of the PRC: In addition to the promulgation of new legislation, it includes the repeal and amendment of existing legislation. Nothing is said about the form of this legislation by the PRC but a number of "Decrees" passed ${ }^{83}$ since this constitutional Decree permit the conclusion that the "Decree" will henceforth be the usual form of Liberian legislation. Therefore, it is this PRC that is the present "Legislature" of Liberia ${ }^{84}$ or, as the noted Liberian jurist Professor Tuan Wreh has put it: "The Legislative Branch (the enactment of military decrees) is under control of the People's Redemption Council. ${ }^{85}$ This is corroborated by the fact, that the PRC has taken over the Capitol Building, the seat of the former Liberian House of Representatives and Senate. ${ }^{86}$

Regarding the membership and size of this new legislative council, the PRC Chairman in his first address to the nation on April 14, 1980 announced a list of 17 names as being the members of the PRC. ${ }^{87}$ However, since the middle of May military personnel began to be named and appear in public as members of the PRC who were not included in the original list. ${ }^{88}$ No of ficially amended list has been published, but around July 1, 1980 a "Re-

83 By of ficial count: 12 (see Footnote 82 above).

84 See "Redemption Almanac" desribed below: "is the highest decision making body exercising executive legislative powers under its Chairman"; also, Art. IV Sect. 2 of the suspended Constitution which refers to the "Legislature" has been copied into the Judiciary Decree (see Footnote 129 below), Section 1.2 with "People's Redemption Council" in place of "Legislature".

85 "Adjudication of Labor Disputes under Military Rule", The Redeemer, Vol. 1 No. 21, 8. 7. 1980, 4.

86 "PRC Members Move To The Capitol", The Redeemer, Vol. 1 No. 2, 3. 5. 1980, 12.

87 Express Special, No. 9, 17.4. 1980, 1 and 2 (full text); The Sunday People, Vol. 2 No. 16, 20. 4. 1980, 8; FOCUS, Vol. 2 No. 16, 13.-19. 4. 1980, 2 and No. 17, 20.-27. 4. 1980, 2.

88 E. g. The Redeemer, Vol. 1 No. 8, 23. 5. 1980, 5 (Tarwuo); Sunday Express, No. 296, 4. 5. 1980, 4 (Brown)= The Redeemer, Vol. 1 No. 12, 6. 6. 1980, 6; The Sunday People, Vol. 2 No. 22, 1. 6. 1980, 10 ("Senior Member Borteh"). Spelling of Liberian tribal names not consistent, e. g. - the new "Senior Member" - "Maj. Jerry Jorwley" is assumed to be identical with the original "Cpl. Jerry C. Friday, Member". 
demption Almanac", a wallposter-calendar for 1980-81, was privately printed and published, but with the following printed note: "This calendar must only be produced by E. J. Tyler - Order by Major General Thomas Weh-Syen, Co-Chairman and Vice-Head of State."

This calendar shows under the heading "Members of the People's Redemption Council Armed Forces of Liberia" 28 military personnel of whom 7 have only a functional title, while the remaining 21 are subdivided into three groups: There are 1 "Senior Member", 9 "Members" and 11 "Co-Members". A comparison of this list with the original list reveals that 3 original members do not appear again, 6 original members are now classified as "Co-Members"; 6 new "Members" and 5 new "Co-Members" do appear, as well. ${ }^{89}$ What organizational or legal significance the various classifications have, is not known. Whether the PRC has found its final definite and constitutional form with this composition or whether further changes and fluctuations will occur is neither known nor predictable.

Section 2 of the Decree refers specifically to the PRC's "Chairman" and in the last, unnumbered provision on taking effect, to the "Head of State". While the Decree does not expressly state it, it is understood from the first announcement of the coup that the of fice of PRC Chairman is identical with the of fice of Head of State. The provision that the legislative powers are "vested in the PRC presided over by its Chairman" can be interpreted that institutionally the of fice of PRC Chairman practically merges the former office of Speaker of the House of Representatives and President of the Senate, and procedurally that the presiding of the PRC Chairman is a legal precondition for the validity and "constitutionality" of all legislative measures of the PRC.

While the Decree itself does not identify any further PRC functionaries, the official announcement of the PRC's composition specified a "Co-Chairman" - now regularly called "Vice-Head of State $"{ }^{90}$-, a "Speaker" and a "Commanding General", the latter often called "the strongman" of the PRC. ${ }^{91}$ The above quoted Almanac, however, adds a "Deputy Commanding General", a "General Secretary", a "Deputy Speaker" as well as the "Senior Member" mentioned above. Whether they have claarly defined functions has not been announced publicly.

In addition, since mid-May so-called "PRC Committees" began to be mentioned in public $^{92}$ without any previous official announcement of their existence, functions or composition. On June 13, 1980 the establishment of different "8 Standing Committees" with

89 Co-Members have been called "Senators", see "Two Co-Members of PRC visit Water Plant ", The Express, No. 24, 23. 7. 1980, 6. However, Commanding General Quiwonkpa agaınst PRC Members posing as "Senators and Repkresentatives", PRC Men Who Claim To Be Politicians Warned," Sunday Express, No. 308, 27. 7. 1980,1 = The Redeemer, Vol. 1 No. 26, 25. 7. 1980, 8: "We're Soldiers, Not Politicians."

90 E. g. The Redeemer, Vol. 1 No. 5, 13. 5. 1980, 8.

91 Sunday Express, No. 297, 11. 5. 1980, 3: "Profile of the Commanding General".

92 E. g. "PRC Committee on Education and Civil Service", The Redeemer, Vol. 1 No. 7, 20. 5. 1980, 8; "PRC Committee on Banking and Currency, "The Sunday People, Vol. 2 No. 22, 1. 6. 1980, 5 and Express Special, No. 17, 4. 6. 1980, 5 (R. G. Zuo); "PRC Committee on Information, Cultural Affairs and Tourism," (W. S. Gould), The Redeemer, Vol. 1 No. 11, 6. 6. 1980, 1. 
different chairmen and 7 or 8 members each was officially announced the titles of which are roughly equivalent with the titles of most major government ministries. ${ }^{93}$ However, the previous committees and their chairmen still seem to hold on and function against the new, official committees ${ }^{94}$ without a clarification being in sight. The functions of the official eight committees were announced as being "to carry on the affairs of the (PR)Council."195

Prof. Wreh has summed up the situation as follows: "The PRC, as we perceive it, acts as the Legislature of the military Government - but this role is limited to making policies, the implementation of which is left to the Head of State and/or his Cabinet, and the Head of State signs the policies or decrees into law. $1{ }^{96}$

However, this opinion overlooks that Section 2 vests not only legislative powers in the PRC but also "all executive powers." Wreh himself realizes: "The Legislative and Executive powers are more concentrated than divided, "but when he continues: "due to the fact that the Head of the Liberian Military Government is the Chairman of both the PRC and the Executive branch ", he neglects Section 2 according to which the PRC is vested with all executive powers as such so that PRC and Executive Branch are actually one and not "both". If Wreh's distinction were true, the 8 Standing PRC Committes would have to be likened to the former House Committees. However, judging by the interference by PRC Members and Committees in the day-to-day activities of Government ministries and agencies, and considering their pressures for appointments and other favours, it appears that the PRC itself sees - and enjoys - its executive powers much more.

\subsubsection{Executive Powers}

According to the quoted Section 2, the Executive powers, too, shall be vested in the PRC presided over by its Chairman. Contrary to its previous one-man or chief-executive, Liberia, therefore, now has a council-type executive or executive council of an unspecified or fluctuating number of persons. The chairman of this new executive council who bef ore and outside of the constitutional Decree has been given the additional and of ficial title "Head of State", a title which is new in Liberian constitutional terminology, is, therefore, not the "Chief Executive" and not identical with the former of fice of Liberian "President" of the suspended Liberian constitution. This is probably understood and the reason why, even though the PRC Chairman is still popularly called "the President",

93 "Highest Decision Making Body Formed", The Redeemer, Vol. 1 No. 14, 13. 6. 1980, 3: 1. "On Executive", 2. "On Commerce, Industry and Transportation", 3. "On Health and Education", 4. "On Public Works" 5. "On Lands and Mines", 6. "On Local Government and Agriculture", 7. "On Labour, Youth and Sports", 8. "On Information"; = Sunday Express, No. 302, 15. 6. 1980, 3. Complete List of all Members: Sunday Express, No. 306, 13.7. 1980, 3.

94 E. g. "PRC Chairman on Agriculture and Forestry, Captain Kolonseh Gonyor," in: "Logging Firms Given Ultimatum," Sunday Express, No. 307, 20. 7. 1980, 5.

95 See Footnote 93 above.

96 See Footnote 85 above. 
this title is studiously avoided in of ficial language. ${ }^{97}$ The PRC Chairman consequently could be said to combine the former offices of the Speaker of the House of Representatives and the President of the Senate with the new of fice of the Chairman of the new executive council.

Section 4 of the constitutional Decree rules: "The Executive Ministries and Agencies of the Republic and the laws relating thereto, shall be in force until they are repealed or amended by the People's Redemption Council."

The Liberian Government Ministries and Agencies as established by the Executive Law $^{98}$ or seperate Acts ${ }^{99}$, have remained unchanged with the exception of the "Ministry of State Without Portfolio" which was abolished, ${ }^{100}$ apparently without any Decree or other legal formalities and thus by verbal amendment of the Executive Law. The Coup, however, has been understood to have - automatically - dismissed all previous ministers and heads of numerous government agencies and public corporation. ${ }^{101}$ Consequently, immediately after the Coup the PRC Chairman appointed new ministers, ${ }^{102}$ among which were three previous ministers ${ }^{103}$ and five were filled with members of the armed forces. ${ }^{104}$ Following the early defection of two of the remaining previous ministers, in $\mathrm{Fe}$ bruary 1981 a reshuffle occurred, in which 5 new ministers appeared, while 2 were switched around and 3 dropped. ${ }^{104 a}$

However, suddenly in June 1980, without previous announcement, the distinction was announced that these Ministers were only "appointed" by the PRC Chairman, but not "confirmed" yet by the PRC. Therefore, "hearings" before a PRC Committee have begun in which the Ministers have to declare their assets and answer the question: "Why do you think we should confirm you as Minister? “105 Several civilian cabinet ministers have

97 However, the "Ministry of State for Presidential Affairs" has been retained, Express Special, No. 8, 15. 4. 1980, 4; Also, "May 14 Declared Public Holiday" by "Presidential Proclamation", The Liberian Inaugural, Vol. 5 No. 20, 14. 5. 1980, 8.

98 Executive Law, Title 13, in: Liberian Code of Laws 1956, Adopted by the Legislature of the Republic of Liberia, March 22, 1956. Published under Authority of the Legislature of Liberia and President William V. S. Tubman, Vol. II, Ithaca, N. Y. (Cornell Univ. Press) 1957, 511-630.

99 E. g. An Act Creating the Forestry Development Authority, Approved Nov. 1, 1976, Published by Authority Government Printing Office, Ministry of Foreign Affairs, Monrovia, Liberia, Dec. 20, 1976 (6 printed, but unnumbered pages); also in: Liberia, Journal of Commerce, Industry and Transportation, Monrovia (Ministry for Commerce etc.), approx. June 1979, 13-14.

100 The Liberian Inaugural, Vol. 5, No. 20, 14. 5. 1980, 8; see recent public demand to abolish "Ministry of Action for Development and Progress", "Streamline Govt. Agencies", The Sunday People, Vol. 2, No. 30, 27. 7. $1980,1=$ New Liberian, Vol. 3 No. $25,31.7$. $1980,5$.

101 E. g. Sunday Express, No. 294, 20. 4. 1980, 1: "Former Officials Tell Military Tribunal«; The Redeemer, Vol. 1 No. 2, 2. 5. 1980.

102 Express Special, No. 8, 15. 4. 1980, 4; West Africa (London), No. 3274, 21. 4. 1980, 689: "Master Sergeant Doe's Cabinet ".

103 Public Works; Health and Social Welfare; Action for Development and Progress.

104 Finance; Agriculture; Commerce, Industry and Transportation; Labor, Youth and Sports; Postal Affairs and Telecommunications.

104a The Liberian Inaugural, Vol. 7 No. 7, 25. 2. 1981,1: "Reshuffle in PRC Government “; Jos Blaise Alima, Révolution ou Pagaille?, Jeune Afrique, No. 1057, 8. 4. 1981, 36-40.

105 Weekend News, Vol. 1 No. 38, 14. 6. 1980, 2. 
questioned what has been called "a prerequisite "106 "before they are commissioned by the Head of State ${ }^{107}$ with the demand that the PRC Members should be subjected to the same confirmation hearings. ${ }^{108}$ This has been refused with the arguments that "the Councilmen have already been commissioned by the Head of State ${ }^{109}$ and "to whom would the PRC Members declare their assets or give testimony for confirmation when they are the Supreme Body of Government presently? "110 This discussion raises a number of constitutional questions; particularly, who actually has the power of "commissioning" or "confirmation", the PRC Chairman or the PRC Members, why was the appointment of the cabinet members which can be assumed to have been done by the then 17 men PRC not considered to be final? It can only be speculated that while the original PRC considered the appointments as final, the subsequently changed and enlarged PRC may have taken a different view. Therefore, it appears that most or even all of the postcoup appointments in Liberia are only considered to be "acting "; as a matter of fact, the continuous, formal commissioning ceremonies of even minor of ficials which characterized the Liberian political life have completely disappeared.

The Liberian Ministries occasionally still sign announcements, eg. "Ministry of Finance, R. L." "111, i. e. of the Republic of Liberia, as before but also "Ministry of Finance, People's Redemption Council A. F. L." ${ }^{112}$, i. e. of the Armed Forces of Liberia. Equally, the usage "Government of the PRC, PRC-Government "113 - the PRC Members conducting the confirmation hearings are called "members of the PRC Government"114 - seems to be on the increase. Thus, the term "Government" appears to be in the process of re-definition in Liberia and the changes which are in process again give the impression of an intended disassolciation from the previous Republic of Liberia which again raises the question of legal identity.

The Ministers form a "cabinet" and are called the "civilian government", as before. It is constitutionally remarkable that no Minister, no member of the Cabinet is a Member of the PRC so that there is a complete, exact division between Cabinet and PRC.

What finally regards the Executive Agencies, they are mainly the 18 Public Corporations or Authorities, ${ }^{115}$ which are of major executive importance and include, inter alia,

106 Sunday Express, No. 302, 15. 6. 1980, 1; The Redeemer, Vol. 1 No. 1 17. 6. 1980, 1; Express Special, No. 18, 11.6. 1980, 1.

107 Sunday Express, No. 301, 8. 6. 1980, 7.

108 Justice Minister Cheapo, Weekend News, Vol. 1 No. 39, 21. 6. 1980, 1: "he had proposed a Decree, yet to be considered by the Council" to the effect.

109 PRC Member H. S. Zuo, Weekend News, Vol. 1 No. 39, 21. 6. 1980, 1.

110 Weekend News, Vol. 1 No. 38, 14. 6. 1980, 2; see also The Liberian Inaugural, Vol. 5 No. 32, 6. 8. 1980, 1: PRC Members "brought together, not selected".

111 E. g. The Sunday People, Vol. 1 No. 16, 20. 4. 1980, 5.

112 E. g. The Sunday People, Vol. 2 No. 16, 20. 4. 1980, 3.

113 E.g. Weekend News, Vol. 1 No. 36, 31. 5. 1980, 1; Sunday Express, No. 299, 25. 5. 1980, 1.

114 The Redeemer, Vol. 1 No. 15, 17. 6. 1980, 1.

115 An Act to Amend the Liberian Code of Laws of 1956 to Provide for a new Title 29A: Public Authorities Law, Approved 19. 2. 1959, in: Acts Passed by the Legislature of the Republic of Liberia during the Session 1958-59, Government Printing Office (Department of State), Monrovia, Liberia 1959, 88-92. 
such diverse agencies as the agricultural export monopoly "Liberian Produce Marketing Corporation, the "National Social Security and Welfare Corporation," the "Liberia Industrial Free Zone Authority" as well as the "Forestry Development Authority", the latter being the equivalent of a Ministry of Forestry and supervising and regulating the third largest exporting sector of the Liberian economy, after iron ore and rubber. ${ }^{116}$ Their structure and performance was criticized already before the coup. ${ }^{117}$ After the coup their Managing and Deputy Managing Directors were arrested and some are still among the political prisoners. ${ }^{118}$ Public criticism of the Public Corporations resumed ${ }^{119}$ and by Executive Ordinance No. 5, of July 4, 1980, their Boards and their control through Ministries were reorganized and shifted. ${ }^{120}$

Prof. Wreh has tried to characterize the new Liberian system as follow. "The head of the Liberian Military Government is the Chairman of both the PRC and the Executive branch," "thus (he) projects the unified command system of the armed forces into the government. "121 However the change from a one-man executive to an executive council and the further diversification of this executive council into 8 Standing Committees which by defination and by inclination are of executive nature, seems to have created a system of undefined, overlapping jurisdiction and powers. The Liberian public has been quick to take advantage of this by playing the PRC, the PRC Committees and individual PRC Members against the Ministries and Agencies. ${ }^{122}$ Indicative of the unresolved structural problem has been a first conflict between a Cabinet Minister and the Chairman of his respective PRC Committee: The Minister of Education dismissed the principal of a government school under his jurisdiction; the Chairman of the PRC Committee on Health and Education who also happens to be the Speaker of the PRC, re-instated the dismissed principal; upon threat of resignation by the Minister of Education, the PRC Chairman appointed a new principal thereby, by implication, upholding the Minister. ${ }^{123}$

116 See e. g. "Liberia 1971-1978: Years of Total Involvement and Fulfilment ", London/Monrovia (Information Ministry), 1978; "Liberia On The Move", Souvenir Brochure, OAU 1979, London/Monrovia (Inform. Ministry) 1979.

117 Dr. Byron Tarr, Public Enterprises in Liberia, The Liberian Outlook, Magazin, Monrovia/Seoul, Vol. 1 No. 12 (Sept. 1978), 27-30 and Vol. 2 No. 2 (Nov. 1978), 220-224.

118 see Footnote 70 above, Group 9.

119 "Students an the New Liberia, "The Redeemer, Vol. 1 No. 4, 9. 5. 1980, 6 (IV,d).

120 See Footnote 41 above; also "Ministries Reorganized", Weekend News, Vol. 1 No. 45, 2. 8. $1980,1$.

121 See Footnote 85 above.

122 PRC Chairman Doe: "Stop Irregular Procedure," Weekend News, Vol. 1 No. 41, 5. 7. 1980, 1 = The Redeemer, Vol. 1 No. 20, 4. 7. 1980, 8; "Yellow Paper Letter", New Liberian, Vol. 3 No. 18, 3. 7. 1980, 5.

123 "Education Minister Threatens To Resign, " New Liberian, Vol. 3 No. 16, 26. 6. 1980, 1; "Gen. Podier Clarifies BWI Issue," The Redeemer Vol. 1 No. 18, 27. 6. 1980, 1; "Podier: Use Proper Channels", The New Liberian, Vol. 3 No. 16, 26. 6. 1980, 6 = Express, No. 20, 25. 6. 1980, 6; "New Principal«, Sunday Express, No. 304, 29. 6. $1980=$ The Sunday' People, Vol. 2 No. 26, 29. 6. 1980, $12=$ Weekend News Vol. 1 No. 40, 28. 6. 1980, 1; See also Wreh (Footnote 85 above) "Only the Head of State can Fire Commissioned Officials," Sunday Express, No. 310, 10. 18. 1980, 1. Now: "PRC, Cabinet Decide to Meet Monthly, "Weekend News, Vol. 1 No. 45, 2. 8. 1980, 1. 
These birth problems of the new Liberian constitutional system as well as the difficulties of the emerging new governmental authority to restore disintegrated army discipline, to curb widespread armed robbery, illegal arrests, occupation of houses, labour and student unrest and lawlessness ${ }^{124}$ may have been a legal factor in the refusal of diplomatic recognition of the new Liberia. The weakness of the Liberian executive and of the whole governmental system could under international law raise the question whether aneffective government, i. e. an executive in political control of the country, existed to satisfy the respective requirement of the traditional three requirements for diplomatic recognition, if not statehood: territory, people, government. That the entity Liberia in its present condition might lack the criterion of an effective government, of this discerning Liberians were uneasily aware themselves. ${ }^{126}$ Of course, it was held that Liberia "can assure the majority of other international entities or states that the Government has complete control over its territory its citiziens and foreign residents in a humane manner . . . 126 With reference to the executions it has been held: "Atrocities committed against humanity in individual countries are considered internal af fairs of their respective countries. "127 thus emphasizing the continuing independence, sovereignty and international equality of Liberia. ${ }^{128}$

\subsubsection{Judiciary}

According to Section 5 of the constitutional Decree "The People's Redemption Council shall set up and establish special tribunals by decrees for handling of matters of judicial nature previously handled by the judicial branch of Government." In implementation of this provision, the PRC, on the same April 24, 1980, issued the Decree "Establishing Special Tribunals For The Administration of Justice", which is subdivided into so expressly called "Sections" from 1.1 to 1.6 without the existence of a Section 2, however. ${ }^{129}$ Section 1.4 makes a passing reference to "the suspended Supreme Court of Liberia" thereby confirming that the total suspension of the Constitution includes the judical system

124 E. g. "Soldiers Rebuked for Acts of Lawlessness," The Redeemer, Vol. 1 No. 29, 5. 8. 1980, 1 Express, No. 26, 6. 8. 1980, 1; Editorial, Weekend News, Vol. 1 No. 45, 2. 8. 1980, 2; "Soldiers Told Not To Occupy Houses Illegaly," Express Special, No. 16, 28. 5. 1980, 1; PRC Chairman Doe, "Soldiers Told to Be disciplined," The Liberian Inaugural, Vol. 5 No. 20, 14. 5. 1980, 6; "For Molestation, Intimidation . . 9 Soldiers Confined," Express Special, No. 15, 21. 5. 1980, 1; "4 Executed by Firing Squad", Sunday Express No. 294, 20. 4. 1980, 5; PRC Chairman Doe, "Corrupt PRC Members To Face Firing Squad,"Weekend News, Vol. 1 No. 36, 31. 5. 1980, 1.

125 Prof. Dr. Wolor Topor, The OAU and the Problem of State Representation, The Redeemer, Vol. 1 No. 3, 6. 5. $1980,5$.

126 Editorial, Weekend News, Vol. 1 No. 32, 3. 5. 1980, 2.

127 Topor, see Footnote 125 above.

128 D. Day, Uniting to Rebuild Liberia, The Redeemer, Vol. 1 No. 5, 13. 5. 1980, 4: Ambassadors in Liberia can "only mean their Govt.'s recognition of the state of Liberia. Whether they recognize the PRC as a de facto government of the Republic of Liberia is another matter." Topor (see Footnote 125 above): non-recognition of Liberian delegations "constitutes a flagrant violation of the principles of international law."

129 Express Special, No. 12, 30. 4. 1980, 2 =Weekend News, Vol. 1 No. 31, 26. 4. 1980, $4=$ The Sunday People, Vol. 2 No 17, 27. 4. 1980, 8 (incomplete) = Decree No. 3 (see Footnote 42a above), 5-7. 
of Liberia as laid down in "Article IV. Judical Department". Consequently, the new Decree "Establishing Special Tribunals" etc., hereinafter referred to as the judiciary Decree, sets up the new judiciary of Liberia.

The term "Special" before tribunal occurs only in Section 5 of the constitutional Decree and in the title of the judiciary Decree. Whether this means that the "People's Supreme Tribunal", the only "tribunal" so far established under the decree, is "special" as opposed to the other - ordinary - courts, which have retained their name "court" is not clear. Under regular legal terminology the term "special" seems neither to apply in the sense of a court for a special jurisdiction, for a special, defined subject matter, nor in the sense of temporary. Therefore, the term must be considered to be meaningless, revolutionary-political language.

\subsubsection{People's Supreme Tribunal}

According to Section 1.1 "the judicial power of this Republic shall be vested in the People's Supreme Tribunal, which is hereby established, and such other subordinate Tribunal as the People's Redemption Council may from time to time establish."

"The People's Supreme Tribunal shall be composed of seven (7) members and one of whom shall be designated Chairman." "The Judges of the People's Supreme Tribunal and all other Judges of the People's Tribunals shall be appointed by the PRC and hold their office during good behaviour but may be removed by unanimous resolution of the People's Redemption Council. The judges shall have salaries established by law, which may be increased but not diminished during their continuance in office. They shall not receive any other remittances or emoluments whatever from parties or others on account of them."

The term "Tribunal" is new in Liberian legal terminology which was used to the term "court." As "Decree", the terms "People's" and "Tribunal" as well as "Chairman" instead of the traditional "Chief Justice, " must be deemed to have been deliberately chosen to express the break with the Liberian past and to emphasize the new revolutionary present. The slip "law" instead of "decree" indicates that, otherwise, language and ruling of Section 1.1 regarding the People's Supreme Tribunal is identical with the suspended Article IV Section 1 the former Supreme Court with two exceptions: The number of justices was limited to one Chief Justice and four Associate Justices (Art. IV Sect. 2), so that an increase by two "members" has occurred, thereby partially fulfilling pre-coup recommendations made because "the creation of four additional counties in 1964 and the subsequent institution of 24 different courts around the country whose judgements were appelable to the Supreme Court had immensely in creased the work of the justices" while "up to 1964 the five justices only heard appeals from five Circuit Courts of the then five counties while the hinterland at the time was governed by native customary law. " 130 The other change is that instead of removal "by the President on the address of two thirds of 
both houses for that purpose or by impeachment and conviction thereon" (Art. IV Sect. 1), removal is now "by unanimous resolution by the PRC."

According to Section 1.2 of the Judiciary Decree "the People's Supreme Tribunal shall have original jurisdiction in all matters affecting foreign ambassadors, other foreign public ministers and consuls and those to which a county or territory shall be a party. In all other cases, the People's Supreme Tribunal shall have appellate jurisdiction both as to law and fact, with such exceptions and under such regulations as the People's Redemption Council shall from time to time decree, "which is identical with the suspended Art. IV Sect. 2 on the jurisdiction of the former Supreme Court, with two notable exceptions: One concernes the reference to the "PRC" which has replaced the word "Legislature" in the original. The other is "and territories", a new amendment reflecting and incorporating that in addition to its nine "Counties", five so-called "Territories" have been created in Liberia over the years, ${ }^{131}$ which have a constitutional and legal statu similar to the Counties in so far that like the Counties they are administered by a "Superintendent", appointed by the Government in Monrovia, but had no Senate representation. The amendment in the Judiciary Decree thus appears to further strengthen the status of the Territories.

Equally, Section 1.3: "A majority of the members of the People's Supreme Tribunal shall be deemed to transact the business of the People's Supreme Tribunal and there schall be no appeal from the decision of the People's Supreme Tribunal" is in substance identical with the supended Art. IV Sect. 3.

Section 1.4: "All other powers, authority and jurisdiction of the suspended Supreme Court of Liberia not in conflict with the provision of any Decres duly issued by the People's Redemption Council shall be exercised by the People's Supreme Tribunal until otherwise ordered by the People's Redemption Council" completes the establishment of the new highest court of the Republic of Liberia.

\subsubsection{Other Tribunals}

Its power to establish "subordinate Tribunals" from time to time (Section 1.1) has not yet been utilized by the PRC. However, a "Military Tribunal" of five members of the armed forces has been established by the PRC "to try former government officials on charges of high treason corruption and misuses of public office ${ }^{132}$ and was instrumental in the shooting of the 13. ${ }^{133}$ But this "Military Tribunal" already began sitting on April 15, 1980, and cannot be considered to fall under Section 1.1 of the Judiciary Decree of April 24,1980 but rather seems to be established by or in connection with the apparently retroactive PRC-"Act on High Treason "134, the first Decree of the PRC. ${ }^{135}$

131 Hasselmann (see Footnote 1 above), Chapter II, $64 \mathrm{ff}$.

132 See Footnote 65 above.

133 See Footnote 67 above.

134 See Footnote 65 above.

135 It is not quite clear whether this "Act" or the equally unnumbered subsequently so-called "Decree relating to Financial Measures" of 15. 4. 1980, New Liberian, Vol. 3 No. 12, 21. 4. 1980, 5 and No. 13, 24. 4. 1980, 9, is No, 1; see also Schmidt (Footnote 4 above). 
Procedurally, this "Military Tribunal" submits its secret verdicts to the PRC which apparently has the final decision and publishes it, a rule which in the case of the 13 who were shot led to public speculations that the "Military Tribunal" had "sentenced " several to life imprisonment but had been overuled by the PRC ${ }^{136}$ of which the members of the "Military Tribunal" do not form part. Subsequently, the "Military Tribunal" has submitted unknown verdicts for another 22 political prisoners on May 13, 1980 to the PRC for confirmation ${ }^{137}$ on which a reaction is still outstanding without explanation. ${ }^{138}$ Since then the "Military Tribunal" has conducted proceedings against 10 further prisoners ${ }^{139}$; apparently no verdicts have been reached and proceedings do not take place anymore without there being any official explanation. Calls for the release of the prisoners who were estimated to number $500^{140}$ have come into the open and are increasing..$^{141}$

What other "subordinate tribunals" the PRC might establish appears unpredictable because all other previously existing courts have been reconstituted.

\subsubsection{Other Courts}

According to Section 1.5 of the Judiciary Decree wall other courts except that of Justices of the Peace in Magisterial Area now existing or which may hereafter be created, are hereby reconstituted with the same powers, authority and jurisdiction as provided in the New Judicial Law of 1972, as amended, except that the title of such courts shall be prefixed by the word "People's" e.g. "People's Civil Law Court of the Sixth Judcicial Circuit, Montserrado County, Republic of Liberia". New Judges shall be appointed by the People's Redemption Council."

The term "reconstituted" does not make it completely clear whether it implies an abolition of the previous and the new establishment of new courts or whether only a reorganisation or modification of the continuing, existing courts is meant. The latter interpretation appears to be the more probable. The exclusion of the Justices of the Peace in Mageisterial Area has led to a legal controversy which has been termed "one of the hottest constitutional debates in recent times between members of the Judicial Branch and the Justice Ministry". ${ }^{142}$ nies Reports", Express Special, No. 12, 30. 4. 1980, 1.

137 The Liberian Inaugural, Vol. 5 No. 20, 14. 5. 1980, $8=$ The Redeemer.

138 Vol. 1 No. 5, 13. 5. 1980, 1; Tribunal Chairman Senkpeni, "the Mansion has not given us any feed back", in: "Should Political Prisoners Be Released?", Weekend News, Vol. 1 No. 45, 19. 7. 1980, 1 see also "Tribunal Members Promoted ", The Liberian Inaugural, Vol. No. 32, 6. 8. 1980, 1.

139 The Liberian Inaugural, Vol. 5 No. 21, 21. 5. 1980, 8.

140 Africa (London), No. 108 (August 1980), 28-29.

141 Foreign Minister Matthews, "Seeks Release of All Political Prisoners, "The Sunday People, Vol. 2 No. 28, 13. 7. 1980, 1; see also Footnote 138.

142 The Redeemer, Vol. 1 No. 12, 6. 6. 1980, 8; The Sunday People, Vol.2 No. 23, 8. 6. 1980, 1; The Redeemer, Vol. 1 No. 14, 13.6. 1980. 


\subsubsection{Appointments}

In implementation of its powers to appoint judges of the People's Supreme Tribunal (Section 1.1) and the judges of the other courts (Section 1.5), the PRC has now made those appointments ${ }^{143}$ and all courts are reopened. ${ }^{144}$ While many judges of the lower courts have been reappointed, none of the judges of the suspended Supreme Court - the Chief Justice being one of the 13 that were shot - have been reappointed. However, some of the newly appointed judges of the People's Supreme Tribunal are noted jurists critical of the previous Government.

Finally, the last Section 1.6 of the Judiciary Decree allows an additional period of 30 days in computing periods of time "due to the recent change of Government."

\subsection{Constitutional Outlook}

After the above overview of the new constitutional developments in Liberia, the closing question arises whether only a "change of Government" occurred and what this "change" means for the future of law and constitution in Liberia. The term "suspended", consistently used in the new PRC Decrees, but so far disregarded in this analysis, means temporarily, for an - of ten specified - time, but not definitely and finally; it thereby often implies a return to the previous, unchanged position. However, to expect Liberia to return to its unaltered Constitution of 1847 must be considered highly unrealistic; it should practically be excluded because popular demands for constitutional review and change are accumulating and permit first glimpses of the Liberia to emerge.

\subsubsection{Specific Changes and Return to Civilian Rule}

Early public demands and petitions call "to set up a Constitutional Committee to study the Constitution, "145 to undertake "a thorough constitutional review so that any new constitution would reflect the true aspirations of all Liberians as one of the first things that should claim our attention when the house-cleaning is finished and done with, "146 "a Constitutional Commission ... to rewrite the Constitution, to work out a new Constitution entirely different from the suspended one. ${ }^{147}$ Prof. Wreh has published a more detailed and comprehensive proposal ${ }^{148}$ calling for a Constitutional Commission to collect popular views and to prepare a draft for a Constitutional Assembly; the study questions

143 Complete List: "Law Courts Reconstituted," The Sunday People, Vol. 2 No. 19, 11. 5. 1980, 3; however, only "Acting Chariman" of the People's Supreme Tribunal; see also "Four New Judges Appointed, "Sunday Express, No. 308, 27. 7. 1980, 1.

144 The Redeemer, Vol. 1 No. 4, 9. 5. 1980, 1; Weekend News, Vol. 1 No. 33, 18. 5. 1980, 5; Sunday Express, No. 2n7, 11. 5. 1980, 1; The Redeemer Vol. 1 No. 13, 10. 6. 1980, 8

145 "Bong Citizens Hail the Revolution," Express Special, No. 14, 14. 1980, 1 ; J. Nyemah, New Liberian, Vol. 3 No. 14, 19.6. 1980, 5 .

146 E. Osadebay, "Towards our National Reconstruction Effort," The Redeemer, Vol. 1 No. 5, 13. 5. 1980, 5.

147 L. R. Shartukar, "A Blueprint for Return to Civilian Rule,"The Redeemer, Vol. 1 No. 12, 6. 6. 1980, 3.

148 "The Return to Civilian Rule, A Constitutional Commission should be Appointed, "The Redeemer, Vol. 1, 29. 4. 1980,6 . 
whether to retain the previous presidential or adopt a parliamentary form of government, whether to keep the previous two-chamber- or change over to a one-chamber-legislature and also contains a number of proposals regarding the therms of office, a judicial service commission, for an independent civil service, as well as for the change of the national motto and the abolition of the property clause. Other writers request the positions of Superintendents of the Counties and Territories to be elective. ${ }^{149}$

When such - or any - constitutional developments will take place is closely connected with the question of Liberia's return to civilian rule. Already a few days after the coup, the PRC Chairman initiated public speculations, if not hopes, with the remark: "When things begin to get on the right track, we, the men and women in arms, will return to the barracks where we belong. ${ }^{150} \mathrm{He}$ has reiterated this recently: "The Government of the PRC would gracefully return to barracks when it is satisfied that the difficulties confronting the country had been minimized. "151 While this has been welcomed, ${ }^{152}$ a PRC Member has come out against a return to civilian Government so soon, ${ }^{153}$ a position which has also found pupolar support; ${ }^{154}$ while popularly already exact time-tables for the return to civilian rule are being advanced and discussed. So it was highly welcomed when in March 1981 a 25-man National Constitutional Commission was ceremoniously inaugurated, its members representing a true Cross-section of Liberia, including a former Secretary of State of President Tubman, i. e. an Americo-Liberian. ${ }^{155 a}$

\subsubsection{The Spirit of Constitutional Developments in Liberia}

What spirit will influence or dominate the return to constitutional government in Liberia, if and when it occurs, will depend on how Liberians will accept or reject their unique social, political, economic, legal and constitutional history which has been uniquely connected and tied with the social, political, economic, legal and constitutional developments of the USA.

149 Shartukar (see Footnote 147 above).

150 "Liberia To Be Built For All," Express Special, No. 11, 23. 4. 1980, 5 = The Liberian Inaugrural, Vol. 5 No. 17, 23. 4. 1980, 8 .

151 "Doe Speaks on Civilian Rule," The Redeemer, Vol. 1 No. 23, 15. 7. 1980, 1 = Express Special, No. 23, 16. $7.1980,1$.

152 A. G. Domah, The Redeemer, Vol. 1 No. 8, 23. 5. 1980, 5; M. P. Gaye, The Redeemer, Vol. 1 No. 11, 3. 6. 1980, 7; Students (see Footnote 119 above), Recommendation II b): "Commission on the Return to Constitutional Rule".

153 Zuo, "Why Civilian Govt. So Soon?", The Redeemer, Vol. 1 No. 7, 20. 5. 1980, 8.

154 C. V. Johnson, "Give Them a Chance," The Redeemer, Vol. 1 No. 20, 4. 7. 1980, 5; A. T. Kpan, "Forget About Civilian Rule Now," The Redeemer, Vol. 1 No. 12, 6. 6. 1980, 5; K. P. Tickey, New Liberian, Vol. 3 No. 14, 19. 6. 1980, 5; "reasonable time"; S. Gotomo, The Redeemer, Vol I No. 16, 20. 6. 1980, 5: "ample Chance".

155 Shartukar (see Footnote 147) above: Commission on Return to Civilian Rule "to oversee the return to civilian rule by April 12; 1984; it should lift the ban on political activities in January 1983"; T. N. Dickson, "Keep Cool," The Redeemer, Vol. 1 No. 12, 6. 6. 1980, 3: "give PRC three years;" J. Nyemah, New Liberian, Vol. 3 No. 14, 19. 6. 1980, 5: return 1983.

155a Lamini Waritay, Avoiding the pitfalls of the past, Africa (London) No. 119 (July) 1981, 55-57. 
While the PRC Chairman had early declared that there will be "no witch-hunting «156 and the Minister of Justice has stated that there will be "no vengeance against AmericoLiberians "157, the PRC Co-Chairman and Vice-Head of State has recently ordered and led the destruction of historical monuments because they were commemorating Americo-Liberian pioneers and settlers. ${ }^{158}$

Petitions are being made to consider not only changing the Liberian flag and the State Motto, but "the names Liberia and Monrovia, the Police Uniforms and the possibility of moving the capital to the interior" because "as Africans the names of Liberia and Monrovia did not fully satisfy the Liberian pepole as reflecting their heritage. $1{ }^{159}$ It has been demanded that: "It is absolutely necessary that the new Constitution of Liberia contains a clause documenting the complete seperation of Church and State" because "The white masters of the Americo-Liberians had used Christianity as a moment of exploitation socially, politically, culturally etc.; they in return had exploited our people by the same identical instrument. "160 Also, it has been advanced that "foreign ideology and symbols were introduced in our Codes of Law and Constitution as a means of seperation, discrimination and exploitation ${ }^{161}$ and petitions request to re-introduce trial by ordeal, formally outlawed in $1976^{162}$ as well as "to recognize the islamic system of marriage. 4163 The Liberian National Bar Association which has lost most of its officers and prominent members either through execution or imprisonment as political prisoners, has also been "redeemed", i. e. reorganized with new officers and has embarked on a new course, ${ }^{164}$,in the spirit of the revolution, $"{ }^{165}$ so that "from now on things are going to be completely different. ${ }^{166}$

156 "Blue Print," Express Special, No. 9, 17. 4. 1980, 5.

157 The Redeemer, Vol. 1 No. 1, 29. 4. 1980, 1; S. Corker, Lib. Embassy Washington, D. C., The Redeemer, Vol. 1 No. 9, 27. 5. 1980, 3: "PRC is not on vengeance mission." See also W. Tubman, Lib. Ambassador U.N., The Redeemer, Vol. 1 No. 6, 16. 5. 1980, 8.

158 "Century-Old Monuments Demolished,"The Liberian Inaugural, Vol. 5 No. 29, 16-7. 1980, 8 = "Greenville Pioneer Monument Demolished “, Sunday Express, No. 307, 20. 7. 1980, 5. See also: "Tearing Down the Decadent Symbols: Confiscation of Properties, Monies Continues. The Redeemer, Vol. 1 No. 22, 11. 7. 1980, 3.

159 Liberian Students in Ohio, Express, No. 21, 2. 7. 1980, 3 and 4 = The Redeemer, Vol. 1 No. 19, 1. 7. 1980, 8. Against: A. G. Raymond, The Redeemer, Vol. 1 No. 36, 25. 7. 1980, 5. See already 1979: S. Henry Cordor, The Study of Af rica, An Introductory Course in African Studies for Liberian Schools, Monrovia 1979, 142 pages (mimeographed), 56-57: "making reforms in our national motto, our flag and other national symbols and domuments and changing of 'Liberia to an Af rican name," his recommendation: "Songhay".

160 Prof. Dr. Wolor Topor, Univ. of Liberia, "The Bennie Warner Dilemma, "New Liberian, Vol. 3 No. 12, 21. 4. 1980, 3.

161 N. Bropleh, "Reviving Liberia's Culture", New Liberian, Vol. 3 No. 22, 17. 7. 1980, 4; see already Cordor (Footnote 159 above).

162 S. D. Lewis, Rivercess, New Liberian, Vol. 3 No. 24, 24. 7. 1980, 5.

163 "Teaching of Queen Recommended," The Redeemer, Vol. 1 No. 24, 18. 7. 1980, 2. See also: "Muslims Call for Islamic Education in All Schools, "The Sunday People, Vol. 2 No. 29, 20. 7. 1980, 5 = Sunday Express, No. 307, 20. 7. 1980, 3.

164 Tuan Wreh, "Redeeming the Masses from Shackles of Legal Exploitation ", The Redeemer, Vol. 1 No. 18, 27. 6. $1980,4$.

165 Justice Minister Cheapo, The Redeemer, Vol. 1 No. 19, 1. 7. 1980, 1.

166 "Bar Association Makes Historic Move," The Redeemer, Vol. 1 No. 19; 1. 7. 1980, $1=$ The Liberian Inaugural, Vol. 5 No. 27, 2. 7. 1980, 8. 
Liberia is clearly in "a revolutionary era" which "is an era of transition. "167 What will eventually emerge out of the tensions, conflicts and contradictions of this transition era, ${ }^{168}$ is too early to predict. However, the trend of developments seems to be clear already: The political, economic and cultural life and on this basis the constitutional and legal character of the new, "Second Republic of Liberia", as it is increasingly called, ${ }^{169}$ will be characterized by an accelerating Africanization. ${ }^{170}$

167 Foreign Minister Matthews, Express, No. 25, 30. 7. 1980, 1.

168 July 26 remains Liberia's Independence Day, PRC Speaker Podier, Weekend News, Vol. 1 No. 43, 19. 7. 1980, 1, see also "Letters" on page 6; "July 26: A Silent Observance," The Redeemer, Vol. 1 No. 27, 29. 7. 1980, 8; Weekend News, Vol. 1 No. 45, 2. 8. 1980, 6.

169 Foreign Minister Matthews, New Liberian, Vol. 3 No. 21, 14. 7. 1980, 1; see already Wreh, Footnote 148 above; Editorial, New Liberian, Vol. 3 No. 25, 31. 7. 1980, 2.

170 Editorial, The Reedemer, Vol. 1 No. 25, 22. 7. 1980, 2: "It has been loo days . . . The indigenous names and personalities are in the fore today and that in itself is representing a great revolutionary change which is irreversible." "Gone are the Dennises, Coopers, the Davids" etc. See already Gerold Schmidt, Die Afrikanisierung Liberias (The Africanization of Liberia), in Internationales Afrika Forum (Munich), No. 4/December 1979, 376-379; Robert Kappel, Liberia -- aus der vollständigen Abhängigkeit von den USA auf dem Weg zur nationalen Entwicklung (Liberia --from total dependence from the USA on the road to national development), in: Afrika Spectrum (Hamburg), Vol. 13/1978, 309-326. 
The New Constitutional Developments in the Republic of Liberia By Gerold Schmidt

The 133-year old constitution of July 26, 1847 of the Republic of Liberia which was closely modelled on the US constitution has been suspended through a military coup of April 12, 1980, declared a revolution against the 133-year old Americo-Liberian rule. The new "constitution" is contained in two Military Decrees of April 24, 1981, the first on "Establishing a System of Orderly Government", the other "Establishing Special Tribunals for the Administration of Justice".

According to the first, the "People's Redemption Council of the Armed Forces of Liberia" - PRC - is vested with all legislative and executive powers when being presided over by its Chairman. The previous, all-powerful Liberian presidency and chief executive is thereby replaced by an executive council the chairman of which is additionally called "Head of State".

While the previous laws in principle remain in force, amendments and new laws are promulgated by the PRC as the new legislative power in the form of Military Decrees. The PRC has formed committees which like the PRC and individuall PRC members show a preference for sometimes independent executive action and less towards concerted legislative work. This affects Ministries, the Cabinet as well as Executive Agencies which have been retained but have partly been filled with military personnel; no Minister is a member of the PRC.

The judicial power has been vested in a "People's Supreme Tribunal" under a "Chairman" which has replaced the previous, smaller "Supreme Court" under its "Chief Justice". The other courts have remained, however, with the addition of "People's" to their respective names. A "Military Tribunal" responsible for the trying of the numerous political prisoners, 13 of whom have been shot, functions outside of the formal judiciary system.

In March, 1981 a 25-men National Constitutional Commission was established and has begun to deliberate on a new Liberian constitution. Popular demands and the aims of the Liberian revolution permit the prediction of an Africanization of the Liberian constitution and legal system.

\section{Cooperative Development in a Repressive Political System By Rolf Baldus}

The Republic of Korea shows quite developed cooperative structures and a very high degree of cooperative organization, especially in agriculture. The repressive political system of the country is, however, reflected in the way the cooperatives and other self-helporganizations work and the analysis offers thus a case study of the specific problems of self-help-organizations in such systems. 